\title{
The implementation of the Fiji Islands Constitution
}

\author{
Yash Ghai
}

This chapter ${ }^{1}$ examines some questions concerning the implementation of the new Constitution of Fiji Islands, adopted in 1997. It might be thought that in light of the successful completion of the 1999 general elections such an examination is redundant.

However, the chapter does not use 'implementation' in the narrow sense of the legislation and the administrative measures which give effect to some or all of the provisions of the Constitution. Rather, it employs it in a teleological sense, to denote the achievement of the objectives of the Constitution. In this sense, 'implementation' also denotes the dynamics of the inner logic of the Constitution, the directions in which it compels, promotes or facilitates change, as well the contradictions within it which may obstruct the achievement of its objectives. In this wider sense, it does not solely refer to measures taken by official bodies alone, important though they are, for various institutions must be funded and resourced, and various policy initiatives taken. Civil society institutions must also play a crucial role in this wider sense. Such a broad view of 'implementation' requires discussion of the objectives of the Constitution and the instruments it has provided for their achievement. Thus, after sketching the framework of analysis, the process by which the Constitution was constructed, and its objectives, the chapter will focus on three issues:

(i) the electoral system; (ii) multiparty government; and (iii) accountability. 


\section{The Constitution as a paradox}

The 1997 Constitution of Fiji Islands is a rich and complex document. Paradoxically, it represents both an affirmation of liberalismespecially significant after the repudiation of liberalism in the 1990 Constitution-and a major qualification on it. This paradox is less the result of confusion on the part of the Fiji Constitution Review Commission (FCRC) (referred to henceforth as the Reeves Commission, after its chair) as rather the legacy of Fiji's constitutional and political history. Nevertheless, the interest of the 1997 Constitution lies precisely in this paradox, for the paradox reflects not only the tortured ethnic history of Fiji but also the more global concern of how to accommodate ethnic and cultural diversity within liberalism (Kymlicka 1989, 1995; Taylor 1994; Tully 1996). The Constitution also marks a break, in different ways, with both earlier Fiji constitutions and with dominant liberal constitutionalism. For those familiar with Fiji's history, the previous sentence itself may seem paradoxical, for earlier constitutions themselves were a negation of liberalism. However, the fact is that the Constitution does not lend itself to simple accounts or explanations. It is rooted both in Fiji's specificity and in more general debates on 'ethnic constitutionalism'.

The new Constitution can be located within contemporary approaches to the constitutional settlement of ethnicity. In the classical liberal paradigm, no distinction is made between members of different ethnic communities. The key organising concept is that of citizenship, which carries with it rights and responsibilities on the basis of the equality of all. Cultural diversity can sometimes be accommodated through federalism, as in Canada for the Francophone community. However, such autonomy is generally fortuitous. For example, US federalism has been rigorously opposed to ethnic federalism, as is manifested in its attitude, until recently, to Puerto Rican claims to statehood, as Puerto Rico's Hispanic traditions were widely considered to be incompatible with the dominant traditions of the United States. In the classical liberal paradigm culture and religion are seen as belonging by and large to the private sphere, and should thus not intrude upon the public domain. More accurately, classical liberalism assumed cultural homogeneity and these possible dilemmas were not fully recognised. It is fair to say that in the negotiations for independent Fiji's first constitution, the leading party of Indo-Fijians, 
the National Federation Party (NFP), pressed for a settlement rooted in the classical liberal paradigm, with its advocacy of the election of the entire legislature by a common roll electorate, a procedure which was also deeply rooted in the history of the Indo-Fijian community in Fiji.

The other approach is to recognise diverse ethnic communities in public law. Within this broad approach, there are three different frameworks, which have little in common. The first is to adopt constitutional provisions designed to provide specific and limited recognition for ethnic groups, particularly minorities, typically through special representation in the legislature, property rights, and/or personal laws. Many such provisions tend to be transitional, for they are located within a constitution which is based on equal citizenship, and which thus aspires to liberalism. Thus, although liberal constitutions seek to disregard cultural and ethnic differences, they may nonetheless reflect an underlying concern with the promotion of national integration. To this end, such a constitution may include provisions such as ethnic equity, independent commissions to remove ethnic discrimination or disabilities, and electoral systems that provide incentives for inter-ethnic cooperation. In some respects Fiji's first Constitution of 1970 seems to fall in this category, for its provision of communal seats was seen as temporary, even though other nonliberal aspects of that Constitution, and particularly the system of administration based on the separation of indigenous Fijians from other groups, were permanent and entrenched.

The second framework proceeds on the assumption of the hegemony of one ethnic community over others (Lustick 1980). Ethnic hegemony ensures political order and stability through the subordination by one community of other communities, who are either disenfranchised completely or are grossly under-represented in the apparatus of the state. Control is a dominant concern of such a system, and as such it operates typically through various forms of coercion, political as well as economic. Colonialism and apartheid South Africa have been classical examples in recent history; while the Jewish dominance of Arabs in Israel, the Protestant dominance of Catholics in Northern Ireland, and the Malay dominance of other ethnic groups in Malaysia are contemporary examples. Such an approach is not inconsistent with the recognition of the culture of the subordinated; indeed, in many instances the recognition in public law of cultural diversity is a central device for subordination. 
The third framework, consociationalism, may be said to be the exact opposite of this control model (Lijphart 1977). It is a response to the inadequacies of the liberal, majoritarian approach in ethnically divided states, which fails to recognise and protect the specific interests of minorities or even significant ethnic groups or to provide a place for them in the decision making of the state apparatus. Consociationalism recognises different communities as corporate groups, with rights and responsibilities. It is premised on the principle that each community should be allowed to participate in the affairs of the state-legislative, executive and public services-in some acceptable proportion. It thus uses a system of pillars and quotas. The leaders of each community have a veto over decisions that they regard as affecting the community's interests adversely. It advocates maximum autonomy for each community over its internal affairs, whether through federalism or some other form of autonomy. Consociationalism is sometimes a description of constitutional arrangements that confer a corporate status on communities, for example by providing communal electoral rolls and/or internal autonomy. It also provides for the cooperation of community leaders in government, as in Bosnia-Herzegovina or the first constitution of independent Cyprus. At other times the term is used to refer to the way a constitution actually works, even though it may not have formal consociational features. For a period of years, Malaysia would have been an example of the latter.

Few constitutions fall neatly into these categories. However, as will be demonstrated below, while the 1970 Fiji Constitution had clear elements of consociationalism, its consociationalism was neither thorough nor equally just to all communities. By way of contrast, the 1990 Constitution provided directly and explicitly for the 'control' system that was in many ways implicit in the 1970 Constitution. The 1997 Constitution is different. Hovering between these paradigms, one may say that the 1997 Constitution uses consociationalism, but in an effort to achieve multiethnic integration. In that sense both the 1970 and 1997 Constitutions were dynamic, in that they sought to restructure ethnic political relationships, as opposed to both the 1990 Constitution and indeed the pure consociationalist model, which do not. However, before turning to the examination of the 1997 Constitution, the process of its making is discussed. 


\section{The role of the Constitution: process}

As conceived by the Reeves Commission, an essential role of the 1997 Constitution of Fiji Islands was to establish and consolidate a national consensus on how the country should be governed. If it succeeded in this aim, it would help to put aside the divisions and the bitterness of 1987 coups and subsequent policies of discrimination. For this purpose it was important to adopt a procedure which would enable a critical examination of the 1990 Constitution. As a part of this, it was also important to give a wide opportunity to individuals, political parties and civic groups to express their views of the past, and their aspirations for the future.

The process underpinning the formulation and the adoption of the 1997 Constitution thus provides a vivid contrast to the procedures used in producing the 1970 and the 1990 Constitutions. The former was drawn up in a series of closed meetings between the political parties, principally the Alliance and the NFP. Differences between them that could not be resolved were settled by the British, particularly at London conferences. There was little public discussion of constitutional issues. The assumption underlying this procedure was that the only way to narrow and resolve ethnic differences was to make the necessary compromises among the élite in private. By way of contrast, the 1990 Constitution was made after the public was invited to make representations to a committee. Public hearings were held to provide legitimacy on the process and the outcome. However, the committee itself was packed with supporters of the coups, and was thus widely perceived by Indo-Fijians to lack impartiality. Consequently, it enjoyed little legitimacy among them.

The Reeves Commission rejected a proposal for its hearings to be held in private, although it allowed a few individuals to present their views on a confidential basis (Fiji Constitution Review Commission (henceforth FCRC) 1996:4.4). It instead promoted a wide consultative process, itself travelling extensively in the country. At the same time, the Commission also believed that it was important to learn from the experiences of other multiethnic countries. Finally, it valued the views of both local and foreign scholars. Consequently, it commissioned and eventually had published a number of studies relevant to its terms of reference, analysing local circumstances and policies, and foreign experiences, including Malaysia, Mauritius and South Africa (Lal and Vakatora 1997a, 1997b). 
The Reeves Commission received in all 852 submissions (FCRC 1996:4.5). Representations were made not only by political groups, but also by religious organisations, trade unions, academics, women's groups, and the Citizens Constitutional Forum, a non-governmental organisation established specifically to promote public discussion of constitutional options, which had itself held consultations with a wide variety of groups before preparing its submission. It is probably fair to say that the issues were reasonably well understood, that all views were canvassed, and there was a high degree of interest in the issues and the process. There was also a thorough review of the 1990 Constitution. As such, there had never before been such an opportunity for all the peoples of Fiji to participate in the constitutionmaking process.

Thoroughness was also manifested in the report and recommendations of the Reeves Commission. The report provides an impartial summary of the submissions it received, particularly from the major political parties. It builds on an emerging local consensus where that is appropriate, but it is not afraid to make innovative proposals that depart from the submissions to it. The report is moreover informed by developments in the international regime of rights and the experiences of other countries. Drawing from a careful analysis of its terms of reference, and without ignoring history, reality and constraints on change in Fiji, the Commission sets out in clear and forthright terms a framework of recommendations which are forward looking and which provide clear directions for change. Granted, the Reeves Commission could only achieve the objectives of its terms of reference through a series of compromises. Nonetheless, its vision for the future of Fiji had a remarkable degree of coherence.

The recommendations of the Commission provided the basis on which the Joint Parliamentary Select Committee made its recommendations to Parliament. Although the Select Committee seems to have accepted the primary national goals spelled out by the Commission, it did not adopt all the recommendations of the Commission, especially on systems of elections and government. However, while the Select Committee did not articulate its own vision or the reasons for it deviating from the Reeves Commission recommendations, it does still seem to have been animated by the overall approach of the Reeves Commission. The Select Committee 
did produce a consensus, which was rapidly transformed into a draft constitution which was given the force of law by a unanimous vote of Parliament, after the recommendations of the Select Committee had received the agreement of the Great Council of Chiefs. The work of the Select Committee and of Parliament, urged on by the leaders of all political parties, was rightly hailed as a breakthrough. It seemed to represent a reconciliation of sorts, but more importantly, a consensus on how Fiji should be governed and how its different communities should relate to each other. It was seen to mark a significant break from past policies and the institutionalisation of ethnic difference, although not as decisively as the Reeves Commission had recommended. In this light, it is not surprising that the 1997 Constitution was widely welcomed in Fiji and abroad.

Although the outcome of the process is to be welcomed, it is not possible to say that the process succeeded in completely reconciling ethnic communities. The terms of reference of the review, concluded after difficult and hard negotiations, had indeed provided a basis for reconciliation and a cooperative search for national consensus. The principal objective of the review was the promotion 'of racial harmony and national unity, and the economic and social advancement of all communities' (FCRC 1996:754-55), goals which seemed to override other virtues like 'democracy'. This objective had been agreed upon after protracted discussions between the government and the opposition, which resulted in support for the review in Parliament. Having been agreed, it might have been expected that it represented an important consensus under which the details of the constitution would have been worked out. However, the 'consensus' was criticised by many Indo-Fijians and indigenous Fijians as a 'sell out'. As a result, and perhaps not surprisingly, a spirit of consensus or amity was not much in evidence as the process unfolded, aggravating the task of the Reeves Commission as it received highly opposed submissions and as the drama of ethnic animosity was rehearsed before it daily. Far from political parties using the process to bring their supporters around the consensus of the terms of reference, some of them incited their supporters to further animosities against other communities. Nor did they try to use the process to establish rapport with leaders of other communities and parties. The lack of that spirit, or what seemed the absence of commitment to the terms of reference by some major 
groups, threatened at times to sabotage the entire review. When agreement was finally reached on the constitution in the Joint Committee as well as in Parliament, it was grudging and half-hearted, with speeches belying the vote many cast, as if many members were acting under coercion. That lack of a complete commitment to the new constitutional dispensation will most probably act as a brake on its full and proper implementation.

Nevertheless, it would be unrealistic to ignore the value of agreement on the Constitution. Even if not all the parties were wholeheartedly behind it, the agreement was based on the recognition that a generally acceptable constitution had to be a compromise; that no community or party could get all of what it wanted. The fact of unanimity, even if some members had reservations, was perhaps demonstrative of a broad recognition of the justice of the Constitution.

\section{The role of the Constitution: objectives}

The purpose of the 1997 Constitution is to provide a basis, on which all of Fiji's communities could agree, for the peoples of Fiji to live together under a system of government. It is intended to bring to an end the social and political stalemate that had resulted from the 1987 coups and the constitutional system that was established as a consequence of the coups. That system was seen to be divisive, apart from its other defects, in failing to provide effective scrutiny of government or a proper system for the protection of rights. As part of its aim to promote a multiethnic ethic and national unity, the Constitution introduced a new electoral system and a new system under which multiparty politics is now conducted. In addition to providing a foundation for inter-ethnic harmony, it is also intended to strengthen the protection of rights and freedoms, bringing the scheme of rights in Fiji into conformity with the international regime of rights. It finally seeks to harmonise group rights with individual rights.

The Constitution goes considerably further than previous Fiji constitutions in establishing a national ethic. It does so by strengthening the protection of human rights, regulating the conduct of leaders to ensure they behave responsibly and honestly, and committing the nation to social justice and the care of the disadvantaged. It also seeks to inculcate values of tolerance and compromise, through respect for the culture and traditions of others. It thus moves away from the stereotypes that have so bedevilled ethnic relations. 
The Constitution was moreover intended to bring Fiji fully back into the community of nations, particularly the Commonwealth. In recent years the Commonwealth has developed a set of norms of rights and democracy to which it seeks to hold its members. It was well understood that Fiji would be re-admitted to the Commonwealth only if its constitution conformed to these norms and to the general international regime of human rights. To that end, a Commonwealth consultant prepared a review of the constitution, noting its substantial conformity with these norms, before Fiji was re-admitted.

The orientation of the 1997 Constitution can be highlighted by contrasting it with its predecessors. The 1970 Constitution was based on the separation of races. Its centrepiece was the electoral system, which was dominated by communal seats and communal voting. Although there was provision for national seats, which had been intended to provide a basis for non-ethnic politics, the logic of communal seats prevailed over the logic of national seats. Moreover, while there was parity of seats between the two major communities, the over-representation of seats for the 'General Electors' roll-that is, those who were deemed to be neither indigenous Fijian nor IndoFijian-was a device designed to ensure the dominance of the executive by indigenous Fijians. In this way the rather deformed Westminster system of the 1970 Constitution not merely kept communities apart politically, but also tended towards the dominance of one group over others.

The 1970 Constitution had clear elements of consociationalism in the establishment of communal rolls. However, its consociationalism was neither thorough nor equally fair to all communities. It did not directly provide for inter-ethnic cooperation; in so far as that was considered desirable, it was left primarily to the voluntary cooperation of ethnic leaders, although the requirement that the Prime Minister consult with the Leader of the Opposition on various state appointments also provided a basis for limited cooperation. The proportionality principle, which was established for the legislature, was not extended to the executive. It was much more solicitous of the interests, property and institutions of indigenous Fijians and of the political interests of 'others' than of Indo-Fijians.

At the same time, it was also possible to regard liberalism as the dominant framework of the 1970 Constitution, for the system of national seats was to be catalyst by which communal politics and communal parties would be transcended. This was reinforced by the 
understanding that the electoral system would be reviewed, in order to provide further incentives for inter-ethnic cooperation. Even if the forward looking recommendations of the electoral review by the Street Commission, which proposed an increase in the number and nature of national seats, making them non-communal and elected on a system of proportional representation, had been adopted, integration would however have been problematic because the separate administrative structure governing indigenous Fijians, termed the 'Fijian Administration', entailed a considerable separation of communities. The rejection of the Street Commission's recommendations shows that the 1970 Constitution may have been perceived by some politicians less in liberal terms than in terms of 'control', whereby political stability, and a measure of multiethnic stability, would be achieved under the hegemony of indigenous Fijians. Indeed, it can be argued that the disenchantment of some politicians with the 1970 Constitution in 1987 arose precisely from the realisation that its liberal impulses were at least as strong as its 'control' orientation.

The silent agenda of the 1970 Constitution, that of political order and stability under the dominance of one ethnic group, made it perhaps comparable to apartheid South Africa and contemporary Malaysia and Israel. However, the 1970 Constitution was constantly under threat from the vagaries of elections for national seats. The overt basis of the 1990 Constitution was to maintain the previously silent agenda while eliminating the threat posed by elections for national seats. The 1990 Constitution therefore removed any vestiges of crosscommunity voting, completing the political separation of ethnic groups, and thus making politics almost exclusively ethnic. In so doing, the 1990 Constitution aimed to ensure the permanent and undisputed rule of indigenous Fijians. It gave a disproportionately large representation to them in both houses of Parliament. Thus, in the House of Representatives 37 out of 70 seats were reserved for indigenous Fijians. In addition it provided that a Prime Minister always had to be an indigenous Fijian. Preferential treatment in, for example, education, public service, and commerce, was to benefit only the indigenous Fijian community (Ratuva, this volume). It also elevated other indigenous Fijian institutions, placing them in important respects over state institutions. As a consequence, it dispensed with the rather awkward, residual agenda of the 1970 Constitution, which 
had as its explicit ultimate aim the development of a multiethnic society in Fiji. The sidelining in this way of Indo-Fijians had an effect that was predictable: factionalism within the indigenous Fijian community, which had been largely contained under the more balanced allocation of communal seats in the 1970 Constitution, emerged.

By contrast, the 1997 Constitution is based on a recognition of Fiji's multiethnic character. It seeks to promote national unity so that all communities are respected and their interests protected. Its electoral system provides clear incentives for multiethnic politics, either through the collaboration of ethnic parties or indeed their replacement by multiethnic parties. It requires a multiparty govemment, in the expectation that leaders from all ethnic groups will participate in the govermment. However, although it is easy to distinguish the 1997 Constitution from its predecessors, its orientation towards multiethnic politics and government is not without ambiguities. It has not, and realistically could not, disregard entirely the burden of the constitutional and political history of the country. In the language of scholars of ethnic relations, it is neither fully consociational nor fully integrative. The entrenchment of extensive provisions for the Fijian Administration and the eminent role given to the Great Council of Chiefs serves to separate ethnic groups and privileges one against all others. Moreover, by providing a framework for indigenous Fijian politics somewhat detached from the national framework, it hinders inter-ethnic integration. Hovering between these paradigms, one may say that the 1997 Constitution uses consociationalism to achieve integration, but for the present consociationalism is more evident. These ambiguities complicate the task of the implementation of the Constitution.

It is clear that the objectives and structure of the 1997 Constitution differ in significant respects from the earlier constitutions. As has been demonstrated, it was adopted after a more participatory process than had previously been the case. As will be seen, it seeks to accommodate shared executive power amongst the major communities, a principle of proportionality in other institutions of the state, and ethnic equity. Its goals are ethnic harmony and national unity, to be achieved by adherence to a national ethic of reconciliation and compromise. Whether political habits generated by previous constitutions can be changed to accord with these new goals and methods is a central question in any examination of implementation. 


\section{Implementing the Constitution}

Several provisions of the Constitution are 'non-executing' and require legislation to be implemented. At the time of writing, some progress had already been made. In addition to legislation concerning the electoral system, including the mechanism for drawing up boundaries, which was used in the 1999 general elections, there is now legislation on: Emergency Powers; an expanded jurisdiction for the Ombudsman; citizenship; the Human Rights Commission; and the Freedom of Information Act. Legislation and administrative machinery have yet to be made for the scheme of chapter 5 , which provides for social justice; and the Code of Conduct for senior state office holders, including Members of Parliament. Consideration of these questions is beyond the scope of this chapter. However, it should be stated that it is important that the necessary legislation and the resources to implement them be provided as soon as possible. The Constitution cannot be separated into compartments. All its parts are integral to its purpose, orientation and method. For example, the strengthening of the protection of rights should be seen as counterbalancing a possible loss, namely parliamentary supervision of government, which may occur with the establishment of multiparty government.

In this section, key provisions of the Constitution relating to the electoral process, multiparty government and accountability will be discussed. Commentary will be offered on some issues relating to their implementation. To recapitulate, the Constitution seeks to establish a multiethnic Fiji, which is understood to be, in the political field, a system in which there is less pre-occupation with ethnicity and a clearer focus on social and economic issues from a broader, national perspective. It is a system in which political parties should coincide decreasingly with ethnicity, and should increasingly be organised along different alignments, such as class or region, however problematic such alignments may be. It is a system in which the concept of citizenship, the Fiji Islander, will replace that of ethnicity.

\section{The electoral system}

The Commission considered that these objectives would be achieved through a combination of rules for institutions and a national ethic, which would animate the functioning of these institutions. There are various provisions in the Constitution which seek to achieve this 
objective. So far as institutions are concerned, it provides for 25 of the 71 seats in the House of Representatives to be open to candidates of any ethnic group and for which all voters resident in the constituency may vote. The voting for these, as for communally reserved seats, is by alternative vote $(\mathrm{AV})$. Under the AV system, a voter has to rank their preference among all the candidates. A winning candidate has to have an absolute majority; if no candidate obtains an absolute majority after the count of first preferences, the second-or subsequent-preferences of those who voted for candidates who came bottom of the poll on the first count are taken into account. The second and subsequent preferences of a voter can thus be crucial in determining the result (Prasad, this volume). In communal seats this method of voting principally serves the purpose of ensuring that the winning candidate enjoys clear majority support. In non-communal 'open' seats, however, its purpose is to provide incentives for political parties to cooperate across ethnic frontiers by opening up possibilities of arrangements between political parties whose core support comes from different ethnic groups. By making recommendations to their supporters concerning second and subsequent votes in open seats, parties can, in effect, try to 'trade' the second and subsequent preferences of their supporters. The trade off can of course take place between parties of the same ethnic group, but since they will be in competition in open constituencies where the members of that ethnic group predominate, trade between political parties of different ethnic groups makes better political sense. Indeed, the logic of the system might well lead to a multiplicity of multiethnic parties; this was the expectation of the Reeves Commission, which recommended it. Additionally, it was expected by the Commission that candidates with moderate views would have an advantage over those espousing extreme views, as they would have a chance of capturing more second preferences (FCRC 1996:9.150-52, 10.31-109; see also Horowitz 1997). The outcome of elections held under the provisions of the Constitution should thus either be coalition government or, better still, government by a party with multiethnic membership.

The Reeves Commission strongly believed that the AV system would operate in this way in open seats; indeed, it was content to propose this system as the only device for a multiethnic government. Since the incentives for cooperation between or the integration of parties would lie in the voting for open seats, it recommended that a 
predominant number of seats -45 out of a total of 70 - should be open seats. Even the 25 communal seats were seen as a transitional arrangement, to be eventually replaced by open seats.

The Joint Parliamentary Select Committee was less willing to take such a bold step. Its indigenous Fijian members wanted to retain a larger number of communal seats. It thus decided, having agreed on a total membership in the House of Representatives of 71, on 46 communal and 25 open seats. Nonetheless, like the Reeves Commission, the Select Committee also favoured a party of government that was multiethnic-a so-called government of national unity. However, in a major dissent from the thinking of the Reeves Commission, it sought to achieve that government by a more direct way-by the Constitution mandating a multiparty cabinet. The Constitution provides that any party with at least 10 per cent of the seats in the House of Representatives is entitled to a proportionate share of cabinet posts. The Reeves Commission recommendation would have retained the essential principle of majority government as in the standard Westminster model, to which it was strongly committed (FCRC 1996:22). By way of contrast, the Constitution creates a major modification of parliamentary government, which will over time undoubtedly raise problems in its operation.

Some implications of the deviation of the Select Committee from the Reeves Commission recommendation can be noted. For a start, although it may sound logical it is not self-evident that the Reeves Commission proposal would have led to cooperation between parties with different ethnic bases, much less to multiethnic parties. Apart from some confusion on the part of the Commission on the technical details of how the proposed system would operate (Arms 1997), the proposed system would have required a very major re-drawing of constituency boundaries to achieve a significant mix of ethnic populations. At best, it would have been difficult to avoid constituencies where one community was not a majority, although it might have been possible to have a number of constituencies with different ethnic majorities, thus facilitating some trade off. Moreover, even if such constituencies were achieved, old habits of ethnic voting would have been likely to continue, and the supporters of a party might well have ignored the advice of the party as to how they should cast their second and subsequent votes, preferring to vote for other candidates of their own ethnicity (Ghai 1997a). 
In the different arrangements under the Constitution, the probability of the AV system working over time in the way that was envisaged by the Reeves Commission becomes even less likely. The number of open seats is only about a third of the total membership of the House of Representatives. Winning open seats thus becomes less crucial to the right to form a government. A party, particularly if rooted in one of the two major ethnic groups, might well decide in future elections to adopt a strategy directed towards winning the more numerous communal seats. If old habits were to persist, the chances are that the strategy would be designed to exploit ethnic divisions by attacking politicians of one's own ethnic affiliation for being soft on other communities.

A better understanding of how the new system might work over time can be obtained through an examination of the electoral experience under the 1970 Constitution. Granted, the new electoral arrangements differ from the 1970 Constitution. However, it remains to be seen whether its logic is significantly different. Under the 1970 Constitution the House of Representatives consisted of 52 members, elected on a combination of 27 communal and 25 national seats. National seats were ethnically allocated but all the voters in the relevant constituency voted for them-hence the system came to be known as 'cross voting'. There were three electoral rolls: for indigenous Fijians, which included Rotumans and other Pacific islanders; for Indo-Fijians; and for General Electors. Indigenous Fijians and Indo-Fijians each had 12 communal and 10 national seats, while the General Electors had 3 communal and 5 national seats. Communal seats were contested on the basis of single member constituencies on a 'first past the post' basis, using communal electoral rolls. For national seats each voter had three votes to cast: one for an indigenous Fijian, one for an IndoFijian, and one for a General Elector. 'First past the post' operated in constituencies where three such members were to be elected.

The logic of the political system was dictated by the communal rather than the national seats. Political parties were organised essentially on ethnic lines, in order to compete for communal seats. There was one dominant party for each of the communities. While the need to contest national seats compelled each of the major parties to extend its appeal beyond the community they principally represented, for the most part this was not successful: each party was content to field a few candidates from other ethnic groups. National seats were 
decided principally by communal votes; thus, indigenous Fijian candidates sponsored by the dominantly Indo-Fijian NFP were successful as a result of Indo-Fijian votes, and so on. This was possible because of the concentration of Indo-Fijians and indigenous Fijians in different parts of the country. Consequently, national seats won by candidates who relied on the vote of the other sponsoring community had little support in their own community, while those who relied on votes from their own communities had little support in other communities. In this way cross-voting seats became an extension of communal seats.

The Alliance Party in the years immediately following independence was a partial exception to this trend. It attracted a significant percentage of Indo-Fijian votes, especially for the crossvoting seats, in which it often achieved over 20 per cent of the vote. By way of contrast, the NFP commonly gained less than 5 per cent of indigenous Fijian votes. However, the Alliance Party had to maintain its support amongst indigenous Fijians if it was to remain a serious political contender, especially as militant indigenous Fijian parties were bidding for the support of its principal electorate. The logic of the system compelled the Alliance Party to progressively champion exclusively indigenous Fijian interests. The disregard by it of IndoFijian interests gradually led to the attrition of its Indo-Fijian support, so that by 1977 it had lost most of it and the parties settled back to relying on their old ethnic constituencies.

The electoral provisions and general circumstances of the 1997 Constitution are sufficiently different that the analogy of earlier experience may be misleading. Nonetheless, it should be noted that in future elections conducted under the 1997 Constitution the incentive to appeal across ethnic frontiers may be reduced by provisions for multiparty government. Any party, which obtains at least 10 per cent of the seats-that is, 8 seats-is entitled to be represented in the govermment. Even an extremist party has a chance to get into the cabinet. Just as a proportional representation system for the legislature tends to produce a multiplicity of parties, so too the low threshold proportionality rule for the cabinet could have the same effect. There is thus a possibility that a multiparty government could in the future emerge in which the partners were somewhat incompatible, if not actually hostile, and the result would be the transference of bitter and fundamental differences from the public arena, via the legislature, to the cabinet. 
Of course, a party with the higher ambition of directing government by providing the Prime Minister would aim for bigger representation. The President appoints as Prime Minister the member of the House of Representatives who, in the President's opinion, can form a government that has the confidence of that House. This formulation, taken from the traditional Westminster system, may not appear to be entirely appropriate for multiparty government if, following an election, the partners were incompatible. However, it would seem that in circumstances where no party obtains an absolute majority of seats the President would need to judge which party leader would be most likely to be acceptable to the other parties which would be eligible to form a government. In normal circumstances the party with the largest representation in the House of Representatives would probably be invited to assemble a cabinet. There is thus still a clear incentive for a party to broaden its appeal across ethnic divides, unless of course it considers that such broadening would alienate its own ethnic supporters. This suggests that politicians wanting to broaden their base of support for the open seats will do so through cooperation between, rather than the integration of, parties. However, even if only that limited progress were made in future elections held under the provisions of the Constitution, it would be an advance upon previous electoral systems.

\section{Multiparty government}

Multiparty government as provided in the Constitution is a new concept for Fiji. It is also rare in other parts of the world. The Fiji provisions are drawn to a large, but not complete, extent from the interim South Africa constitution, on which the joint submission of the NFP-Fiji Labour Party (FLP) to the Reeves Commission was based (NFP-FLP 1995). While the Constitution is relatively specific on the method for the formation of multiparty government, it has few provisions for its operation. In such circumstances, a few cautious speculations on how multiparty government may function can be offered.

In Section 97 the Constitution establishes the principle that the government must have the confidence of the House of Representatives. As already noted, the process of the formation of government starts with the appointment by the President of a member of the House of Representative who, in the President's judgement, can form a 
government that has the confidence of the House. This rule, contained in Section 98, is no different from previous constitutions, but its operation may not be as straightforward as before, particularly as the configuration of parties will change under the impetus of the new electoral system. The concept of 'the confidence of the House' may also take on a new colouration because of the fact that all the major parties are entitled to be part of government. It would be normal for the President to appoint the leader of the largest party as Prime Ministerdesignate, as happened following the 1999 general elections. However, if in the future the largest party does not have a majority in the House, and instead two smaller parties, who had formed an electoral pact under which they had agreed to support for appointment to the prime ministership the leader of the larger of the two parties in the House, had a majority between them, the President would in all likelihood call upon that leader to form a government. The bargaining between parties which was witnessed following the 1999 general elections has thus in all probability become embedded within the process under which a government in Fiji is formed. Indeed, in the future the President may have to engage in much more extensive consultations with party leaders before deciding whom to appoint as Prime Minister. It is to be hoped that this will not lead to the horse trading and bribery that has become endemic in Papua New Guinea before the vote for the Prime Minister on the floor of the House (Ghai 1997b).

Sections 99(5) and 99(7) of the Constitution entitle but do not compel any political party to join the cabinet. The Prime Minister has to invite eligible parties to join government, but they may decline, as occurred after the 1999 general elections. It is important to underscore this point; although there is an element of voluntariness in the arrangements, much of the analysis of the possible difficulties facing multiparty government in the future is based upon the assumption that every eligible party will join the cabinet. Constitutionally, it does not appear that the Prime Minister can impose conditions on the invitation to other parties to join the cabinet. If the Prime Minister's party needed the support of other parties to form a government, these parties would then be in a strong position to negotiate policies that would bind the government. However, if the Prime Minister's party had a majority or substantial numbers, it might exercise a hegemonic role, and other parties might be compelled into compliance with its priorities. 
It is clear that despite the outcome of the 1999 general elections smaller parties-that is, those with less than 8 members-will in all likelihood be less favourably placed than before, for previously they might have held the balance between two major and opposing groups. Now their support will seldom be crucial, unless a major party opts to stay out of government and to oppose it, as happened following the 1999 general elections, or unless their support was crucial for a major party during elections. Moreover, such smaller parties will not be entitled to enter the cabinet. Granted, Section 99(6) of the Constitution does permit the Prime Minister to appoint as minister a member of such a party, but only by sacrificing a ministerial post from the quota of the Prime Minister's party. This provision was designed, it would seem, for the benefit of those parties which seek to represent General Electors. While a concern for minorities is no doubt commendable, the provision betrays a continuing obsession on the part of those who framed the Constitution with ethnically based parties, and goes against the logic of multiparty government.

According to Section 99(1), the Prime Minister decides on the appointment of ministers. However, when appointing persons from participating parties the Prime Minister has to consult with the leader of that party. Section 103 holds that the Prime Minister alone decides on the allocation of portfolios, while Section 99(1) holds that the Prime Minister also decides on the dismissal of ministers. Obviously, in both cases the Prime Minister will do well to consult with the leaders of other parties in the cabinet. The Prime Minister would effectively have to do so in the case of dismissal, for the post that becomes vacant would have to replaced after consultation with the leader of the relevant party. In most Westminster systems, the Prime Minister is no longer primus inter pares (one member of a collective leadership), as in constitutional theory, but effectively the one who makes the key policy and administrative decisions of the government. Such is not the case under the 1997 Constitution, and while this would not create a major constitutional problem if the government consisted of one party, it could become problematic in case of coalitions. Moreover, in the case of the Fiji Constitution the problems and difficulties may be even greater, for two reasons. The first reason is that the purpose of multiparty government is power sharing, which could be negated if the Prime Minister were not to consult other partner parties. The second reason is that multiparty government is mandated by the 
Constitution, and is not a voluntary arrangement. A 'forced' marriage of this kind requires utmost sensitivity, consultation and compromise, and therefore effectively changes the nature of the office of the Prime Minister.

The Constitution provides relatively few rules for the functioning of the cabinet. It is not clear, for example, how far the Prime Minister has to consult with or act in accordance with the advice of the cabinet in the exercise of functions directly vested in the Prime Minister's Office. The Prime Minister plays an important role in the appointment of key officers such as the Ombudsman, the Human Rights Commission, heads of departments and secretary to the cabinet, presidents of certain tribunals, and the Chief Justice. The Prime Minister exercises other powers as well, including the important one, introduced through a 1998 amendment, Section 5(2), of advising the President on the dissolution and proroguing of Parliament. Through Section 102 the cabinet is collectively responsible to the House for the governance of the state, which means that all ministers must support the policy decided by the cabinet, even if the minister or the party the minister represents has voted against that policy in the cabinet. The collective responsibility of the cabinet may deprive representatives of these parties from voicing in public their disagreement with official policies. This may put them in a dilemma, for to retain the support of their followers they may need to distance themselves from the government of which they are a part. Alternatively, since the lure of office is so powerful in Fiji, as in other states, politicians may seek to stay in government and yet criticise it in public. However, this would put a strain on cabinet unity and effectiveness. Yet it would seem that the Prime Minister could not expel such a party from the government, for the sanctions for breach of collective responsibility are political and not legal. This is in and of itself interesting, in that in other respects the Constitution transforms many issues and decisions that are political in the traditional Westminster system into legal ones.

It would seem, following from the above discussion, that inadequate attention was paid in the drafting of the Constitution to the operation of multiparty government. For example, the rules for individual and collective responsibility of ministers owe more to the traditional Westminster system than to one that enjoins power sharing. The difficulty may have arisen from slavishly adopting the Reeves Commission's proposal on the parliamentary system, which, as has 
already been mentioned, was not well disposed towards compulsory power sharing, favoured a traditional Westminster system, and was in any event rather conservative on recommendations for the executive. It will be necessary, for the proper functioning of multiparty government, to establish agreement amongst the parties or develop conventions or even possibly laws as to the method of decision making in the cabinet and the way in which the Prime Minister can exercise directly vested functions. The proper functioning of multiparty government will require that such decisions be made in consultation with the cabinet, or at least with leaders of political parties participating in government. It is also necessary to reconsider the role of collective responsibility. One function served by the rule of collective responsibility is to maintain the unity of the government in the face of an opposition ever keen to replace it through a vote of no confidence. A vote of no confidence against the kind of government established by the Constitution is however unlikely, unless the participating parties fall out, and it may be that they are more likely to fall out due to the presence of the collective responsibility rule than its abolition. On the other hand, some modified rule of collective responsibility or some convention will be needed to ensure that there is basic respect for policies adopted by the cabinet, especially if the rules for decision making become more consensual. Multiparty government provides the possibility of moving away from adversarial to more consensual modes of parliamentary business as well, which would also provide for a more meaningful role for backbenchers, as discussed in the next section.

Even with such conventions, there may be problems. Discipline within the government may come under strain because of the multiplicity of parties within it. There may be tendencies towards 'inner' and 'outer' groups in the cabinet. The budgetary process, and the special role of the minister of finance, may lead to the exclusion of some political groups or change the nature of the process. Consensus may be hard to establish. Parties which, once in the cabinet, are expected to cooperate, may have fought against each other in the elections, perhaps leaving resentment and bitterness in their train. If extremist parties eventually find their way into government, they will make ethnic accommodations difficult, for the probability is that they will be quick to accuse other parties of their own ethnic affiliation of selling the community 'down the river'. Instead of consensus and cooperation, there may be veto and blockage. 
It therefore has to be acknowledged that despite the outcome of the 1999 general elections constitutional provisions for elections or for multiparty government by themselves will not necessarily achieve ethnic cooperation or harmony. Indeed, it is seldom that constitutions have such an ineluctable outcome. Their provisions are meditated by and through institutions, the judiciary and the public service, and perhaps most importantly, by politicians and their parties. This is particularly true of the two sets of provisions that have been examined above-the electoral system and multiparty government. It was for this reason that the Reeves Commission emphasised the ethics of the nation under the new dispensation. It said that

Racial harmony is not merely an absence of conflict. It connotes a positive attitude by the members of each community towards those of other communities, based on mutual respect and trust, a sympathetic appreciation of one another's values and traditions, and tolerance of different beliefs, customs and cultural attitudes (FCRC 1996:3.45).

National unity connotes a willingness of all communities to work towards common goals. It must be built on the existing foundation of shared interests and values, including the loyalty and commitment to the country of all its citizens. The shared citizenship of the members of the indigenous and the non-indigenous communities alike gives them the right to participate in national life and the conduct of government (FCRC 1996:3.47).

Racial harmony and national unity should be promoted by reducing or eliminating sources of tension between communities. Their shared interests values and priorities should be recognised. All communities are interdependent. Every community should therefore regard the major concerns of another community as national concerns, whose solution is essential in their own interests, as well as the interests of the whole country (FCRC 1996:3.50).

So important did the Commission consider these attitudes to politics and to inter-ethnic relations that it proposed to make them part of the national ethic - and a constituent part of national political morality - by incorporating them in a Compact to be included in the Constitution. Paragraphs 7 and 8 of the Compact are of special interest. Paragraph 7 says that in 'forming a government, and in that government's conduct of the affairs of the nation through the promotion of legislation or the implementation of administrative policies, full account should be taken of the interests of all communities'. Paragraph 8 says that to 'the extent that the interests of 
different communities are seen to conflict, all interested parties should enter into negotiations in good faith in an endeavour to reach agreement'.

The Commission also considered that the behaviour of leaders is fundamental to the improvement of inter-ethnic relations, although there is no express provision in the Compact on this point. Nonetheless, its views are worth quoting in full since they are so central to the conduct of electioneering and the exercise of power. It said

Political, religious and other community leaders, together with individual community leaders, have a responsibility, both in public and in private, to show good sense, moderation and sensitivity in their comments on, and behaviour towards, members of other communities. They should refrain from attributing characteristics to the members of other communities on the basis of a stereotype or the behaviour of a particular person. They should also refrain from displaying racial prejudice themselves or attributing racial prejudice to others (FCRC 1996:3.50).

Short of the non-binding Compact, the Commission found no way to institutionalise these roles and norms. They establish a social agenda, the responsibility for which lies in large part with civil society. This point is discussed in the conclusion, highlighting the role of many private institutions and processes in the implementation of the Constitution.

\section{Accountability}

Understandably, most of the negotiations over the Constitution and much of the discussion since its adoption have focused on its ethnic dimensions. Consequently, not much attention has been paid to one of the major objectives of the Constitution, particularly as recommended by the Reeves Commission, which in turn built upon the recommendations of the Citizens Constitutional Forum and the joint submission of the NFP-FLP. This objective is to enhance the accountability of the government; to ensure clean and honest government and officials; and to promote parliamentary as well as public participation in the processes of decision making and supervision of the conduct of government. Various measures have been adopted for this purpose: Section 174 requires freedom of information legislation; Section 156 requires a Code of Conduct to regulate the behaviour and conduct of politicians and senior officials, 
in order to ensure integrity and honesty; Section 74(3) promotes an increased role of parliamentary back benchers through sector standing committees; and Section 42 strengthens the office of the Ombudsman and establishes the Human Rights Commission.

It could be argued that despite these provisions there might be less scrutiny and supervision of government under the new Constitution, as the leaders of all the key political parties are in most instances likely to be in the cabinet. Various factors suggest why there is likely to be less of the traditional type of accountability than before. For a start, there will be a lesser role for the opposition, or more accurately, the opposition will not be able to play an effective role. No party may accept clear responsibility for government policy, since this would entail blaming its partners. The electorate may not be offered a clear choice; and even if it is, the platform on which a party may have fought the election may need to be modified in cabinet to produce a consensus. Decision making may become less open, being made in the secrecy of the cabinet, while at the same time being protected from scrutiny by the principle of collective responsibility. Finally, because all major political parties may, at some point in the future, be in the cabinet the effectiveness of backbenchers may decrease, especially if party procedures for expulsion of its members are invoked or are threatened to be invoked.

The new mechanisms for participation and accountability introduced by the Constitution, if properly implemented, will to some extent make up for the loss of accountability that may emerge over time as the new arrangements for multiparty government are implemented. However, it is unlikely that they will be sufficient by themselves. It is necessary to reflect on the new arrangements to consider how the political process itself can be modified to enhance accountability. The following measures would help towards, and some are essential for, effective accountability.

Political parties play an enhanced role under the new Constitution. Unless the parties are well organised and are themselves democratic and accountable, the chances of wider parliamentary or executive accountability are slim. The Reeves Commission probably overrated the stability and vibrancy of political parties in Fiji when it said that it believed that 'the party system is deeply embedded in the political culture' (FCRC 1996:2.75; for a critique, see Ghai 1997a:155-6). For either that reason or for its general conservatism in legal policy, the 
Commission rejected the proposal of the NFP and FLP that the Constitution should provide for the regulation of political parties. Perhaps Parliament could now be persuaded to enact appropriate legislation.

A particular problem regarding the role of political parties is that under Section 71(1) (h) a political party can disqualify any of its parliamentary members from their seat in the House by the simple expedient of expelling them from the party. The only exception to this wide rule is if the member was expelled for action taken by them in their capacity as a member of a parliamentary committee, in which case they retain their parliamentary seat even though no longer a member of that party. As section 71 is formulated, MPs are not protected against expulsion for their views on the floor of the House. However, freedom of expression and the acceptance of dissent by MPs are particularly necessary under the new arrangements. Another way to deal with party intolerance is firm legislation to regulate the process and procedure of political parties, which was urged on the Commission by both the NFP and FLP.

There are other ways too in which backbenchers can help in the supervision of the executive. The role of parliamentary select committees, to cover the scrutiny of the administration and of Bills and subsidiary legislation, can be a vital factor in creating an active role for backbenchers. No minister can be a member of a select committee, which means not only that the committees should be more independent of the government, but also that its members, particularly the chair, should develop their own expertise in order to be more effective. The select committees can also enhance public participation in supervision as well as policymaking by, for example, holding public hearings and consultations, giving a platform to individuals, trade unions, non-governmental organisations and other groups to make submissions to them on government policies and legislative proposals. These hearings should be open to the public and should be broadcast. Of course, if the committees are to discharge their responsibilities effectively they must be supplied with the necessary resources, including training. This in turn requires that some of the conventions of the traditional Westminster system need to be modified, as in the Standing Orders, or rules of party discipline in Parliament, in recognition of the significantly new system set up by the Constitution. 
Public participation in law making can also be enhanced through changes in the process of law making. As is customary in many countries, a consultative paper containing an explanation and justification should precede legislative proposals. The paper can be used by all interested parties as the basis by which consultations are held. Ample time should be allowed for public comments. The government should set up machinery to review these comments and should be open to the revision of the policy accordingly. It may be argued that this process would slow down law making-but this may be precisely its virtue, for laws made with deliberation and after full consultation not only result in more acceptable laws, but also more effective laws.

Then there is the role of the Leader of the Opposition. What role they play will depend greatly on whether there is a party with substantial public and parliamentary support which is willing to forgo its participation in the government and to assume the role of the opposition. The formal role of the Leader of the Opposition is not much different from that under the 1970 Constitution. For example, under Section 64(1) (c) the Leader of the Opposition nominates 8 members of the Senate; under Section 132(1), the Leader of the Opposition has to be consulted on the appointment of the Chief Justice; under Sections 75(3)(4) and 78(8) respectively, the Leader of the Opposition must be consulted on the Constituency Boundaries and Electoral Commissions. In addition, the functions given to the Leader of the Opposition under the Standing Orders would presumably continue, as would the resources provided to the office for the discharge of its responsibilities. While it is important for the objectives of the Constitution that all major ethnic groups should be in the cabinet, it is not necessary that all major parties should also be in the cabinet. Indeed, it could be argued that the objective of honest government, which is effectively accountable to Parliament and the public, needs an effective Leader of the Opposition. Moreover, in keeping with the multiethnic aspirations of the Constitution it is important that the opposition party strives to include all ethnic groups so that criticisms are not seen, nor can they be dismissed, as merely ethnically motivated. The salience of this issue was highlighted in the aftermath of the 1999 general elections, when an ethnically based party emerged as the principal opposition to a multiethnic government. 
However, above all else there is a challenge to civil society to ensure fair policies by, as well as accountability of, government. Social and non-governmental organisations should follow the conduct of government and proceedings in Parliament, they should provide audits of departments and parastatal bodies, use reports of the Auditor-General to raise questions about the probity of government, ensure that the Freedom of Information legislation is put to good use, that education about human rights is disseminated to the public, and that they supplement the work of the Ombudsman and the Human Rights Commission in appropriate ways. They have to highlight arbitrariness and corruption within government when it occurs. An informed and concerned citizenry is the ultimately the best safeguard against these practices. No democracy can function or survive without their vigilance.

\section{Conclusion}

Constitutional provisions are a mix of rules, norms and institutions. Perhaps the easiest part of implementation is the setting up of institutions. It is much harder to ensure that institutions and their office holders follow the norms that have been established. Much depends on the balance between the institutions of the executive and the institutions of control and accountability. Some assistance can be had from the rules; some rules are more likely to generate the results desired of them, others less so. For example, it is generally said that electoral laws are very efficacious, for politicians make an effort to understand them and are influenced in the pursuit of power by the incentives or disincentives provided by them (Sartori 1968), a view which had much influence with the Reeves Commission. The implementation of a constitution also depends on the commitment of citizens to its values and the ability of civic groups to mobilise in support of its objectives. The dominance of ethnic consciousness can have a major impact on how the constitution operates, particularly its electoral laws; and a rights ideology is particularly hard to inculcate, for the outrage that might otherwise be felt at the violation of rights is channelled into building ethnic hostilities. A constitution does not, as a rule, break down if its norms and values are not honoured; rather, it then works in quite different, and perverse, ways from that originally 
envisaged and desired (Ghai 1997b). This analysis suggests that there are no guarantees that the 1997 Constitution of Fiji Islands will achieve its goals.

While the 1997 Constitution represents a consensus, it does not have universal approval. The terms of reference of the review represented agreement between the government and the opposition as to the future direction for the governance and development of Fiji. The process by which the Constitution was made ensured the careful consideration of all alternatives. It was based on the unanimous recommendations of the Reeves Commission, on which there were nominees of the two major communities who pursued the interests of both their community as well as that of Fiji as a whole. The Great Council of Chiefs sanctioned it. It was adopted unanimously by Parliament. Most have welcomed it as being best able to tackle Fiji's contemporary problems.

The Constitution provides a framework and institutions. These seek to direct policymaking and the manner of the exercise of state power, but they cannot by themselves determine how politics will be conducted. The Constitution may be hard to operate without goodwill and flexibility, as it is based on compromises, balances, and even contradictions. There will be need for frequent negotiations. It is now the obligation and responsibility of all involved in the process, and particularly politicians, to support the Constitution and to ensure that it is implemented in the spirit that animates it. A particularly heavy responsibility lies on political parties.

Nonetheless, unless public attitudes and practices support a constitution, there is no guarantee that its purposes will materialise. Constitutional provisions are dependent on wider community commitment and practices; they depend on the view the public takes of the values the Constitution seeks to promote. Political and religious leaders must behave responsibly, promoting tolerance of and respect for other communities. Any person, and even more so a leader, who seeks to inflame racial animosity is in gross violation of the Constitution. While there is of course a limited role for the law in establishing these norms and values, it is, in the final instance, Fiji Islanders who must exercise their rights of citizenship to ensure the accountability of government and the observance by leaders of the spirit of the Constitution. 
The prospects for the success of the Constitution are promising, especially in the aftermath of the 1999 general elections. In the near future there is bound to emerge be a new set of leaders from within Fiji's communities. These leaders are likely to have studied together and forged some kind of friendship during their student days. Many of them will enjoy the multiethnic and cosmopolitan nature of Fiji society. Moreover, the process of the review of the 1990 Constitution and the adoption of the 1997 Constitution have produced a new understanding of the problems facing the country. The awareness of the social, economic and political costs of the coups is now clear. Public support for inter-ethnic equity and social justice has thus grown. At the same time, the imperatives of globalisation are incompatible with a return to some form of narrow ethnicism. Further, the demography of Fiji is changing, to the clear advantage to indigenous Fijians. This should make indigenous Fijian leaders more relaxed about the political process, regardless of electoral and parliamentary rules. Perhaps most importantly, there is a palpable pride among key leaders, their supporters and people at large at having achieved a fair and popular constitution in difficult circumstances, and perhaps, as a result, a commitment to making Fiji as the world should be.

\section{Endnote}

1. This chapter was written before the 1999 general elections, being based on the inaugural Citizens Constitutional Forum 'Constitution Matters' Lecture, held on 27 August 1998 at the University of the South Pacific, Suva, Fiji. The chapter was not revised in light of the outcome of the elections, in large part because the results have reinforced the salience of the analysis contained in the chapter. The author is grateful to the Committee on Research and Conference Grants of the University of Hong Kong for a grant. He also wishes to thank Peter Larmour for valuable comments on a draft of the chapter. 
This text is taken from Confronting Fiji Futures, edited by A. Haroon Akram-Lodhi, published 2016 by ANU eView, The Australian National University, Canberra, Australia. 